\title{
Effect of Non-genetic Factors on Monthly Milk Yield for Phule Triveni Cattle
}

\author{
Swapnali Uttamrao Rokade*, DilipKundalik Deokar, Ghoshita Suryakant Hingonekar \\ and Harshavardhan Shahaji Sonawane
}

Department of Animal Husbandry and Dairy Science, College of Agriculture Dhule, Mahatma Phule Krishi Vidyapeeth, Rahuri, India

*Corresponding author

\section{A B S T R A C T}

\begin{tabular}{l} 
Keyw or ds \\
Phule Triveni, \\
MMY1, MMY2, \\
MMY3, MMY5, \\
MMY6, MMY7, \\
MMY8, MMY9, \\
MMY10 \\
\hline Article Info \\
$\begin{array}{l}\text { Accepted: } \\
\text { 04 December 2020 } \\
\text { Available Online: } \\
\text { 10 January } 2021\end{array}$ \\
\hline
\end{tabular}

The data on production performance of Phule Triveni cattle maintained at Research cum Development Project on Cattle (RCDP), Mahatma Phule Krishi Vidyapeeth, Rahuri district, Ahmednagar, (M.H) were utilized for present study. The least squares means of monthly milk yield $(\mathrm{kg})$ were estimated by considering the effects of period of calving, season of calving and lactation order as nongenetic factors. The effect of period of calving was significant on traits MMY1, MMY9 (P>0.05), from MMY2 to MMY8, MMY10 ( $<<0.01)$. The effect of season of calving was significant in MMY9 $(\mathrm{P}>0.05)$, MMY7 $(\mathrm{P}<0.01)$ while it was non significant on all the traits viz, MMY1 to MMY6, MMY8 and MMY10. The effect of order of lactation was significant on traits MMY4, MMY5, MMY6 ( $\mathrm{P}>0.05)$, MMY 1 to MMY $3(\mathrm{P}<0.01)$, while it was non significant on traits from MMY 7 to MMY 10.

\section{Introduction}

Increased pressure for intensified milk production and simultaneous rise in environmental temperature due to global warming has increased the thermal load on dairy animals. Elevated environmental temperature combined with high humidity causes discomfort and escalates the stress level in animals which is reflected in terms of reduced physiological and metabolic activities that results in reduced growth, drop in production and reproduction in farm animals. Heat stress is one of the most vital environmental stressor that has negative impact on milk yield, milk composition (fat $\%$, SNF\%, protein \% etc). Construction of Temperature Humidity Index (THI) by combining several climatological parameters like dry bulb, wet bulb temperature along with relative humidity to quantify the thermal stress is one of the best methods to assess heat stress on animals. Several research workers have reported that there exists a threshold THI value, above which the negative effects of heat stress is observed on animals. Mitigation strategies to combat heat stress includes selection of heat tolerant animals and their 
breeding, inclusion of heat tolerance as a trait while constructing selection index, providing balanced nutrition to the animals and implementation of good ventilation along with suitable cooling system in the farm (Behera et al., 2020).

\section{Materials and Methods}

The data of Phule Triveni cows maintained at Research Cum-Development Project on Cattle, M.P.K.V., Rahuri for a period from 2009 to 2019 (10 years) were collected for present investigation for following Traits:

a)Productive traits:1) Total lactation milk yield (kg),2) Lactation length (days),3) Dry period (days),4) Peak milk yield (kg).

To examine the Production traits, the research data was classified into 3 periods of calving viz. $\mathrm{P}_{1}$ (2009-2011), $\mathrm{P}_{2}(2012-2014), \mathrm{P}_{3}$ (2015 above); 3 seasons of calving, viz. $S_{1}$ (Rainy) June- September, $\mathrm{S}_{2}$ (Winter) OctoberJanuary and $\mathrm{S}_{3}$ (Summer) February-May; 5 order of lactation viz. $\mathrm{L}_{1}$ first lactation, $\mathrm{L}_{2}$ second lactation, $\mathrm{L}_{3}$ third lactation, $\mathrm{L}_{4}$ fourth lactation, $\mathrm{L}_{5}$ fifth lactation

The effects of non-genetic factors like period of calving, season of calving and parity were estimated by using least-square analysis as suggested by Harvey (1990). The model was used with the assumption that different components being fitted into the model were as linear, independent and additive. The model used was as follows:

\section{Model I}

$Y_{i j k l}=\mu+A_{i}+B_{j}+C_{k}+e_{i j k l}$

where $Y_{i j k l}$, observation of $1^{\text {th }}$ animal, $k^{\text {th }}$ parity, $\mathrm{j}^{\text {th }}$ season of calving, $\mathrm{i}^{\text {th }}$ period of calving; $\mu$ overall mean, $A_{i}$ fixed effect of $i^{\text {th }}$ period of calving ( 1 to 3 ), $B_{j}$ fixed effect of $j^{\text {th }}$ season of calving (1 to 3 ), $\mathrm{C}_{\mathrm{k}}$ fixed effect of $\mathrm{k}^{\text {th }}$ parity (1 to 5$) ; \mathrm{e}_{\mathrm{ijk} l}$ random error $\sim$ NID $(0$, $\left.\sigma^{2} e\right)$.

\section{Duncan's Multiple Range Test (DMRT)}

Duncan's Multiple Range Test as modified by Kramer (1957) was used to make pair wise comparison among the least square means with the use of inverse elements and root mean squares for error.

If the values:-

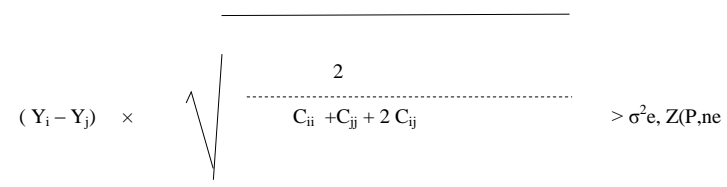

Where,

$Y_{i}-Y_{j}$ : Difference between two least squares means

$\mathrm{C}_{\mathrm{ii}}$ : Corresponding $\mathrm{i}^{\text {th }}$ diagonal elements of $\mathrm{C}$ matrix

$\mathrm{C}_{\mathrm{jj}}$ : Corresponding $\mathrm{j}^{\text {th }}$ diagonal elements of $\mathrm{C}$ matrix

$\mathrm{Z}$ (P, ne): Standardized range value in Duncan's table at the chosen level of probability for the error degrees of freedom

P: Number of means involved in the comparison

$\sigma^{2} \mathrm{e}$ : Root mean squares for error

\section{Results and Discussion}

\section{First monthly milk yield}

The mean for monthly milk yield (MMY) records of MMY1 observed in Phule Triveni cows under present investigation were 391.69 
$\pm 9.34 \mathrm{~kg}$. The present values were closer to those reported in FJG (Jadav, 1993) and JFG (Dange, 1996) cattle. However, higher MMY values were reported in FG cows (Patil, 1989) and lower values in IBFG (Jebale, 1994), JG (Naikare, 1993) and IJFG cows (Dange, 1996).

The variation due to period of calving in monthly milk yield of first was significant in Phule Triveni cows $(\mathrm{P}<0.01)$.Similar results were obtained in $\mathrm{HF} \times$ Girhalfbreds (Deokar et al., 2017), Phule Triveni cows (Kamble, 2014), Kale et al., (2001a) in Triple cross bred, Raut et al., (2017) in HF×Girhalfbreds. In Phule Triveni, monthly milk yield of first $(\mathrm{kg})$ of cows calved during various period of calving was significantly differed from each other. The results revealed that the monthly milk yield of first month linearly decreased in cows calved during succeeding periods over preceding i.e. $\mathrm{P}_{1}$ to $\mathrm{P}_{3}$ in Phule Triveni cows.

The variation due to season of calving in first monthly milk yield was non-significant in Phule Triveni cows. This result was in accordance with Deokar et al., (2017) in HF $\times$ Girhalfbreds, Kamble (2014) in Phule Triveni cows and Pandey et al., (2018) and Raja (2019) in Sahiwal cattle, Raut et al., (2017) in $\mathrm{HF} \times$ Girhalfbreds. However contradictory results were obtained by Kale et al., (2001a) in Triple cross bred. In Phule Triveni, the highest MMY1 was observed in cows calved during summer $(406.11 \pm 15.36)$ than rainy season $(389.02 \pm 16.02)$ and lowest in winter (379.92 \pm 15.32$)$.

The difference due to order of lactation in first monthly milk yield was significant $(\mathrm{P}<0.01)$ in Phule Triveni cows. Similar results were obtained by Kale et al., (2001a) in Triple cross bred. In Phule Triveni, the highest MMY1 (kg) was observed in cows during $\mathrm{L}_{4}(427.32 \pm 21.44)$ followed by $\mathrm{L}_{5}(424.99 \pm 25.44), \quad \mathrm{L}_{3}(415.83 \pm 19.29)$,
$\mathrm{L}_{2}(384.41 \pm 17.32)$ and lowest in $\mathrm{L}_{1}(305.88 \pm$ 17.29)lactation. In Phule Triveni cows in the present study no specific trend was noticed for MMY1 in various lactations. The difference in MMY1 among total cows calved during $\mathrm{L}_{4}$ and $\mathrm{L}_{5}, \mathrm{~L}_{2}$ and $\mathrm{L}_{3}, \mathrm{~L}_{2}$ and $\mathrm{L}_{1}$ were at par to each other.

\section{Second monthly milk yield}

The overall least squares mean of second monthly milk yield in Phule Triveni cows was $370.44 \pm 9.29 \mathrm{~kg}$.

The influence of period of calving on second monthly milk yield was significant $(\mathrm{P}<0.01)$ in Phule Triveni cows. Similar results were reported in HF $\times$ Girhalfbreds (Deokar et al., 2017), Phule Triveni cows (Kamble 2014), Kale et al., (2001a) in Triple cross bred, Raut et al.(2017) in HFxGirhalfbreds. In Phule Triveni cows, monthly milk yield of second month $(\mathrm{kg})$ of cows calved during period $\mathrm{P}_{1}$ $(426.46 \pm 14.07)$ was significantly higher than those $\mathrm{P}_{2}(358.24 \pm 13.83)$ and $\mathrm{P}_{3}$ (326.61 \pm 18.99$)$ which were at par to each other. The differences in second monthly milk yield among total cows calved during $\mathrm{P}_{1}$ was significantly higher than $\mathrm{P}_{2}$ and $\mathrm{P}_{3}$. The difference in MMY2 among total cows calved during $\mathrm{P}_{3}$ and $\mathrm{P}_{2}$ were at par to each other. The results revealed that the monthly milk yield of second month linearly decreased in cows calved during succeeding periods over preceding i.e. $\mathrm{P}_{1}$ to $\mathrm{P}_{3}$ in Phule Triveni cows.

The variation due to season of calving in second month milk yield was non-significant in Phule Triveni cows. This result was in accordance with Deokar et al., (2017) in HF × Girhalfbreds, Kamble (2014) in Phule Triveni cows and Pandey et al., (2018) and Raja (2019) in Sahiwal cattle, Raut et al., (2017) in HF $\times$ Girhalfbreds. However contradictory results were obtained by Kale et al., (2001a) in Triple cross bred. In Phule Triveni, the 
highest MMY2 was observed in cows calved during winter $(381.93 \pm 15.23)$ followed by summer $(379.95 \pm 15.27)$ and lowest in rainy (349.43 \pm 15.92$)$.

The difference due to order of lactation in second month milk yield $(\mathrm{kg})$ was significant $(\mathrm{P}<0.01)$ in Phule Triveni cows. Similar results were obtained by Kale et al., (2001a) in Triple cross bred. In Phule Triveni, the highest MMY2 (kg) was observed in cows during $\mathrm{L}_{4}(410.78 \pm 21.30)$ followed by, $\mathrm{L}_{5}$ (395.22 \pm 25.08), $\quad \mathrm{L}_{3}(382.37 \pm \quad 19.17)$, $\mathrm{L}_{2}(366.16 \pm 17.60)$ and lowest in $\mathrm{L}_{1}(297.66 \pm$ 17.18) lactation. The difference in MMY2 among total cows calved during $\mathrm{L}_{4}$ and $\mathrm{L}_{5}, \mathrm{~L}_{2}$ and $\mathrm{L}_{3}$ and $\mathrm{L}_{5}, \mathrm{~L}_{2}$ and $\mathrm{L}_{1}$ at par to each other. In Phule Triveni cows in the present study no specific trend of lactation order was noticed for MMY2.

\section{Monthly milk yield 3}

The overall least squares mean for monthly milk yield of third month in Phule Triveni cows was $333.59 \pm 8.78 \mathrm{~kg}$. The influence of period of calving on monthly milk yield of third month in Phule Triveni cows was significant $(\mathrm{P}<0.01)$. Similar results were reported in $\mathrm{HF} \times$ Girhalfbreds (Deokar et al., 2017) and Phule Triveni cows (Kamble 2014), Kale et al., (2001a) in Triple cross bred, Raut et al., (2017) in HF×Girhalfbreds. In Phule Triveni, monthly milk yield of third month $(\mathrm{kg})$ in cows calved during $\mathrm{P}_{1}(383.08$ $\pm 13.30), \quad \mathrm{P}_{2}(316.45 \pm 13.08)$ and $\mathrm{P}_{3}$ $(301.23 \pm 17.95)$ was significantly differed from each other. The results revealed that the monthly milk yield of third month linearly decreased in cows calved during succeeding periods over preceding i.e. $\mathrm{P}_{1}$ to $\mathrm{P}_{3}$ in Phule Triveni cows.

The variation due to season of calving in MMY3 was non-significant in Phule Triveni cows. This result was in accordance with
Varshney and Tomar (1982) in Hariana and different crossbred cattle, D. K. Deokaret al., (2017) in HF $\times$ Girhalfbreds, Kamble (2014) in Phule Triveni cows, Pandey et al., (2018) and Raja (2019) in Sahiwal cattle, Raut et al.(2017) in HF $\times$ Girhalfbreds. However contradictory results were obtained by Kale et al., (2001a) in Triple cross bred. In Phule Triveni, the highest MMY3 (kg) was observed in cows calved during winter season (348.37 \pm 14.40$)$ followed by summer (338.46 $\pm 14.43)$ and lowest in rainy $(313.93 \pm 15.05)$.

The difference due to order of lactation in third monthly milk yield $(\mathrm{kg})$ was significant $(\mathrm{P}<0.01)$ in Phule Triveni cows. Similar results were obtained by Kale et al., (2001a) in Triple cross bred. In Phule Triveni, the highest MMY3 $(\mathrm{kg})$ was observed in cows during $\mathrm{L}_{4}(363.94 \pm 20.14)$ followed by, $\mathrm{L}_{5}$ $(360.60 \pm 23.71), \quad \mathrm{L}_{3} \quad(337.64 \pm 18.12)$, $\mathrm{L}_{2}(331.09 \pm 16.64)$ and lowest in $\mathrm{L}_{1}(274.67 \pm$ 16.25) lactation. The difference in MMY3 among total cows calved during $\mathrm{L}_{4}$ and $\mathrm{L}_{5}, \mathrm{~L}_{3}$ and $\mathrm{L}_{2}, \mathrm{~L}_{2}$ and $\mathrm{L}_{1}$ were at par to each other. In Phule Triveni cows in the present study no specific trend of lactation order was noticed for MMY3.

\section{Fourth Monthly milk yield}

The overall least squares mean for monthly milk yield of fourth month in Phule Triveni cows under was $299.73 \pm 8.37 \mathrm{~kg}$. The influence of period of calving on monthly milk yield of fourth month was significant $(\mathrm{P}<0.01)$ in Phule Triveni cows. Similar results were reported in $\mathrm{HF} \times$ Girhalfbreds (Deokar et al., 2017), Phule Triveni cows (Kamble 2014), Kale et al., (2001a) in Triple cross bred, Raut et al., (2017) in HF $\times$ Girhalfbreds. In Phule Triveni, monthly milk yield of fourth month $(\mathrm{kg})$ of cows calved during different period viz., $\mathrm{P}_{1}(349.78$ $\pm 12.69), \quad P_{2}(278.29 \pm 12.47)$ and $P_{3}$ $(271.12 \pm 17.42)$ was significantly different 
from each other. The results revealed that the monthly milk yield of forth month linearly decreased in cows calved during succeeding periods over preceding i.e. $\mathrm{P}_{1}$ to $\mathrm{P}_{3}$ in Phule Triveni cows. The variation due to season of calving in fourth monthly milk yield was nonsignificant in Phule Triveni. This result was in accordance with Deokar et al., (2017) in HF $\times$ Girhalfbreds, Kamble (2014) in Phule Triveni cows, Manjari Pandey et al., (2018) and Raja(2019) in Sahiwal cattle, Raut et al., (2017) in HF $\times$ Girhalfbreds. However contradictory results were obtained by Kale et al., (2001a) in Triple cross bred. In Phule Triveni, the highest MMY4 (kg) was observed in cows calved during winter $(312.61 \pm 13.73)$ followed by summer $(295.80 \pm 13.77)$ and lowest in rainy season (290.78 \pm 14.35$)$.

The difference due to order of lactation in fourth monthly milk yield $(\mathrm{kg})$ was significant $(\mathrm{P}<0.05)$ in Phule Triveni cows. Similar results were obtained by Kale et al., (2001a) in Triple cross bred. In Phule Triveni cows, the MMY4 was observed in cows calved during order of lactation $\mathrm{L}_{4}(326.28 \pm 19.21)$ followed by $\mathrm{L}_{3}(319.82 \pm 17.28), \mathrm{L}_{2}(289.30 \pm$ $15.87)$ and $L_{1}(251.32 \pm 15.49)$ and lowest in $\mathrm{L}_{5}(311.95 \pm 22.62)$ lactation. In Phule Triveni cows in the present study no specific trend of lactation order was noticed for MMY4 in various lactations.

\section{Monthly milk yield 5}

The overall least squares mean for monthly milk yield of fifth month in Phule Triveni cows was $270.54 \pm 8.43 \mathrm{~kg}$. The influence of period of calving on monthly milk yield of fifth month was significant $(\mathrm{P}<0.01)$ in Phule Triveni cows. Similar results were reported in HF $\times$ Girhalfbreds (Deokar et al., 2017), Phule Triveni cows (Kamble 2014), Kale et al., (2001a) in Triple cross bred, Raut et al., (2017) in HF $\times$ Girhalfbreds. In Phule Triveni, monthly milk yield of fifth month $(\mathrm{kg})$ of cows calved during period $\mathrm{P}_{1} \quad(324.27$ $\pm 12.77), \quad \mathrm{P}_{2}(247.37 \pm 17.23)$ and $\mathrm{P}_{3}$ $(239.99 \pm 12.55)$ was significantly different from each other. The difference in monthly milk yield of fifth month among total cows calved during period $\mathrm{P}_{1}$ was significantly higher than $\mathrm{P}_{2}$ and $\mathrm{P}_{3}$. The results revealed that the monthly milk yield of third month linearly decreased in cows calved during succeeding periods over preceding i.e. $\mathrm{P}_{1}$ to $\mathrm{P}_{3}$ in Phule Triveni cows.

The variation due to season of calving in monthly milk yield of fifth was nonsignificant in Phule Triveni cows. This result was in accordance with Deokar et al., (2017) in HF $\times$ Girhalfbreds, Kamble (2014) in Phule Triveni cows, ManjariPandey et al., (2018) and Raja (2019) in Sahiwal cattle, Raut et al., (2017) in HF $\times$ Girhalfbreds. However contradictory results were obtained by Kale et al., (2001a) in Triple cross bred. In Phule Triveni cows, the highest MMY5 (kg) was observed in cows calved during season winter $(293.55 \pm 13.82 \mathrm{~kg})$ followed by summer $(264.83 \pm 13.86 \mathrm{~kg})$ and lowest in rainy season $(253.26 \pm 14.45 \mathrm{~kg})$. The difference due to order of lactation in monthly milk yield of fifth $(\mathrm{kg})$ was significant $(\mathrm{P}<0.05)$ in Phule Triveni cows. Similar results were obtained by Kale et al.(2001a) in Triple cross bred $(207.63 \pm 4.42)$. The MMY5 $(\mathrm{kg})$ of cows calved during order of lactation $\mathrm{L}_{3}(298.66 \pm 17.40 \mathrm{~kg})$ is significantly higher thanL $L_{5}(275.36 \pm 22.77 \mathrm{~kg}), \mathrm{L}_{2}(262.36 \pm 15.98$ $\mathrm{kg})$ and $\mathrm{L}_{1}(227.84 \pm 15.60 \mathrm{~kg})$ and at par with those calved during $\mathrm{L}_{4}(288.49 \pm 19.33 \mathrm{~kg})$. In Phule Triveni, the highest MMY5 (kg) was observed in cows calved during $\mathrm{L}_{3}(298.66 \pm 17.40)$ followed by, $\mathrm{L}_{4}(288.49 \pm$ 19.33), $\mathrm{L}_{5}(275.36 \pm 22.77), \quad \mathrm{L}_{2}(262.36 \pm$ 15.98) and lowest in $\mathrm{L}_{1}(227.84 \pm 15.60)$ lactation. In Phule Triveni cows in the present study no specific trend was noticed for MMY5 in various lactations (Table 1 and 2). 
Table.1 Least Square means of MMY 1 TO MMY 5 in Phule Triveni Cattle

\begin{tabular}{|c|c|c|c|c|c|c|}
\hline \multirow[t]{2}{*}{ Effect } & \multirow[t]{2}{*}{$\mathbf{N}$} & \multicolumn{5}{|c|}{ LEAST SQUARE MEANS } \\
\hline & & MMY 1 & MMY 2 & MMY 3 & MMY 4 & MMY 5 \\
\hline$\mu$ & 137 & $391.69 \pm 9.34$ & $370.44 \pm 9.29$ & $333.59 \pm 8.78$ & $299.73 \pm 8.37$ & $270.54 \pm 8.43$ \\
\hline \multicolumn{7}{|c|}{ Period of Calving } \\
\hline $\mathbf{P}_{1}$ & 53 & $434.26^{\mathrm{a}} \pm 14.16$ & $426.46^{\mathrm{a}} \pm 14.07$ & $383.08^{\mathrm{a}} \pm 13.30$ & $349.78^{\mathrm{a}} \pm 12.69$ & $324.27^{\mathrm{a}} \pm 12.77$ \\
\hline $\mathbf{P}_{2}$ & 55 & $387.39^{\mathrm{b}} \pm 13.92$ & $358.24^{\mathrm{b}} \pm 13.83$ & $316.45^{\mathrm{b}} \pm 13.08$ & $278.29^{\mathrm{b}} \pm 12.47$ & $239.99^{c} \pm 12.55$ \\
\hline $\mathbf{P}_{3}$ & 29 & $353.41^{c} \pm 19.11$ & $326.61^{\mathrm{c}} \pm 18.99$ & $301.23^{\mathrm{c}} \pm 17.95$ & $271.12^{c} \pm 17.12$ & $247.37^{b} \pm 17.23$ \\
\hline \multicolumn{7}{|c|}{ Season of Calving } \\
\hline $\mathbf{S}_{1}$ & 44 & $389.02 \pm 16.02$ & $349.43 \pm 15.92$ & $313.93 \pm 15.05$ & $290.78 \pm 14.35$ & $253.26 \pm 14.45$ \\
\hline $\mathbf{S}_{3}$ & 47 & $406.11 \pm 15.36$ & $379.95 \pm 15.27$ & $338.46 \pm 14.43$ & $295.80 \pm 13.77$ & $264.83 \pm 13.86$ \\
\hline \multicolumn{7}{|c|}{ Lactation Order } \\
\hline $\mathbf{L}_{1}$ & 35 & $305.88^{c} \pm 17.29$ & $297.66^{c} \pm 17.18$ & $274.67^{c} \pm 16.25$ & $251.32^{c} \pm 15.49$ & $227.84^{c} \pm 15.60$ \\
\hline $\mathbf{L}_{2}$ & 33 & $384.41^{b} \pm 17.72$ & $366.16^{\mathrm{b}} \pm 17.60$ & $331.09^{b} \pm 16.64$ & $289.30^{b} \pm 15.87$ & $262.36^{\mathrm{b}} \pm 15.98$ \\
\hline $\mathbf{L}_{3}$ & 30 & $415.83^{a b} \pm 19.29$ & $382.37^{\mathrm{ab}} \pm 19.17$ & $337.64^{\mathrm{b}} \pm 18.12$ & $319.82^{\mathrm{ab}} \pm 17.28$ & $298.66^{\mathrm{a}} \pm 17.40$ \\
\hline $\mathbf{L}_{4}$ & 23 & $427.32^{\mathrm{a}} \pm 21.44$ & $410.78^{a} \pm 21.30$ & $363.94^{a} \pm 20.14$ & $326.28^{\mathrm{a}} \pm 19.21$ & $288.49^{\mathrm{ab}} \pm 19.33$ \\
\hline $\mathbf{L}_{5}$ & 16 & $424.99^{a b} \pm 25.24$ & $395.22^{\mathrm{ab}} \pm 25.08$ & $360.60^{\mathrm{ab}} \pm 23.71$ & $311.95^{\mathrm{ab}} \pm 22.62$ & $275.36^{\mathrm{ab}} \pm 22.77$ \\
\hline
\end{tabular}

Table.2 Least Square means of MMY 6 TO MMY 10 in Phule Triveni Cattle

\begin{tabular}{|c|c|c|c|c|c|c|c|c|c|c|}
\hline Effect & $\mathbf{N}$ & MMY6 & $\mathbf{N}$ & MMY7 & $\mathbf{N}$ & MMY8 & $\mathbf{N}$ & MMY9 & $\mathbf{N}$ & MMY10 \\
\hline$\mu$ & 137 & $234.97 \pm 7.90$ & 136 & $165.13 \pm 8.48$ & 131 & $168.05 \pm 7.49$ & 113 & $162.12 \pm 8.14$ & 98 & $146.12 \pm 7.95$ \\
\hline \multicolumn{11}{|c|}{ Period of Calving } \\
\hline $\mathbf{P}_{1}$ & 53 & $294.23^{\mathrm{a}} \pm 11.93$ & 53 & $220.13^{\mathrm{a}} \pm 12.79$ & 53 & $215.19^{\mathrm{a}} \pm 11.14$ & 53 & $188.27^{\mathrm{a}} \pm 10.60$ & 42 & $179.71^{\mathrm{a}} \pm 10.90$ \\
\hline $\mathbf{P}_{2}$ & 54 & $211.48^{\mathrm{b}} \pm 11.83$ & 54 & $138.25^{b} \pm 12.69$ & 49 & $141.28^{c} \pm 11.59$ & 55 & $141.76^{\mathrm{c}} \pm 12.68$ & 33 & $118.99^{c} \pm 12.49$ \\
\hline $\mathbf{P}_{3}$ & 29 & $199.19^{c} \pm 16.10$ & 29 & $137.00^{c} \pm 17.27$ & 29 & $147.67^{b} \pm 15.06$ & 29 & $156.33^{\mathrm{b}} \pm 16.47$ & 23 & $139.65^{b} \pm 15.17$ \\
\hline \multicolumn{11}{|c|}{ Season of Calving } \\
\hline$S_{1}$ & 43 & $227.23 \pm 13.62$ & 43 & $170.84^{\mathrm{b}} \pm 14.61$ & 41 & $172.28 \pm 13.04$ & 44 & $189.86^{\mathrm{a}} \pm 13.59$ & 32 & $153.70 \pm 12.91$ \\
\hline $\mathbf{S}_{2}$ & 46 & $265.46 \pm 12.91$ & 46 & $191.77^{\mathrm{a}} \pm 13.85$ & 45 & $184.49 \pm 12.15$ & 46 & $155.03^{\mathrm{b}} \pm 11.70$ & 39 & $132.35 \pm 11.36$ \\
\hline$S_{3}$ & 47 & $212.22 \pm 12.94$ & 47 & $132.77^{\mathrm{c}} \pm 13.88$ & 45 & $147.37 \pm 12.29$ & 47 & $141.47^{c} \pm 13.94$ & 27 & $152.29 \pm 14.15$ \\
\hline \multicolumn{11}{|c|}{ Lactation Order } \\
\hline $\mathbf{L}_{1}$ & 35 & $203.66^{c} \pm 14.57$ & 35 & $149.72 \pm 15.62$ & 35 & $150.38 \pm 13.61$ & 35 & $152.40 \pm 13.39$ & 28 & $135.45 \pm 12.99$ \\
\hline $\mathbf{L}_{2}$ & 33 & $225.29^{\mathrm{b}} \pm 14.92$ & 33 & $164.53 \pm 16.01$ & 31 & $170.50 \pm 14.40$ & 33 & $164.04 \pm 14.35$ & 26 & $152.47 \pm 13.49$ \\
\hline $\mathbf{L}_{3}$ & 30 & $252.54^{\mathrm{a}} \pm 16.25$ & 30 & $179.05 \pm 17.43$ & 29 & $193.97 \pm 15.33$ & 30 & $180.03 \pm 15.48$ & 22 & $148.80 \pm 15.22$ \\
\hline $\mathbf{L}_{4}$ & 22 & $241.63^{\mathrm{ab}} \pm 18.42$ & 22 & $172.31 \pm 19.76$ & 20 & $158.58 \pm 18.03$ & 23 & $158.78 \pm 19.86$ & 13 & $123.90 \pm 19.38$ \\
\hline $\mathbf{L}_{5}$ & 16 & $251.72^{\mathrm{ab}} \pm 21.26$ & 16 & $160.02 \pm 22.81$ & 16 & $166.81 \pm 19.86$ & 16 & $155.36 \pm 21.93$ & 9 & $169.96 \pm 22.81$ \\
\hline
\end{tabular}




\section{Monthly milk yield 6}

The overall least squares mean of monthly milk yield of sixth month in Phule Triveni cows was $234.97 \pm 7.90 \mathrm{~kg}$.

The influence of period of calving on monthly milk yield of sixth month was significant $(\mathrm{P}<0.01)$ in Phule Triveni cows. Similar results were reported in $\mathrm{HF} \times$ Girhalfbreds (Deokar et al., 2017), Phule Triveni cows (Kamble 2014), Kale et al., (2001a) in Triple cross bred, Raut et al., (2017) in HF×Girhalfbreds. In Phule Triveni, monthly milk yield of sixth month $(\mathrm{kg})$ of cows calved during period $\mathrm{P}_{1}(294.23 \pm 11.93)$ was significantly higher than those in $\mathrm{P}_{2}(211.48 \pm$ 11.83) and $P_{3}(199.19+ \pm 16.10)$ which were significantly different from each other. The results revealed that the monthly milk yield of sixth month linearly decreased in cows calved during succeeding periods over preceding i.e. $\mathrm{P}_{1}$ to $\mathrm{P}_{3}$ in Phule Triveni cows.

The variation due to season of calving in monthly milk yield of sixth month was nonsignificant in Phule Triveni cows. This result was in accordance with Deokar et al., (2017) in HF $\times$ Girhalfbreds, Kamble (2014) in Phule Triveni cows, Pandey et al., (2018) and Raja (2019) in Sahiwal cattle, Raut et al., (2017) in HF $\times$ Girhalfbreds. However contradictory results were obtained by Kale et al., (2001a) in Triple cross bred. In Phule Triveni, the highest MMY6 $(\mathrm{kg})$ was observed in cows calved during season winter $(265.46 \pm 12.91$ $\mathrm{kg})$ followed by rainy $(227.23 \pm 13.62 \mathrm{~kg})$ and lowest in summer $(212.22 \pm 12.94 \mathrm{~kg})$. The MMY6(kg) of cows calved during season $\mathrm{S}_{2}$ is significantly higher than $\mathrm{S}_{3}$, and at par with those calved during $S_{1}$.

The difference due to order of lactation in monthly milk yield of sith month $(\mathrm{kg})$ was significant $(\mathrm{P}<0.05)$ in Phule Triveni. Similar result was reported in Triple cross bred by
Kale et al.(2001a). In Phule Triveni, the highest MMY6 (kg) was observed in cows calved during $\mathrm{L}_{3}(252.54 \pm 16.25)$ followed by, $\mathrm{L}_{5}(251.52 \pm 21.26), \mathrm{L}_{4}(241.63 \pm 18.42), \mathrm{L}_{2}$ (225.29 \pm 14.92$)$ and lowest in $L_{1}(203.66 \pm$ 14.57) lactation. In Phule Triveni cows in the present study no specific trend was noticed for MMY6 in different lactations.

\section{Monthly milk yield 7}

The overall least squres mean of monthly milk yield of seventh month in Phule Triveni cows was $165.13 \pm 8.48 \mathrm{~kg}$. The period of calving on monthly milk yield of sevent month was significant $(\mathrm{P}<0.01)$ in Phule Triveni cows. Similar results were reported in HF×Girhalfbreds (Deokar et al., 2017) and Phule Triveni cows (Kamble 2014), Kale et al., (2001a) in Triple cross bred. In Phule Triveni cows, monthly milk yield of seventh month $(\mathrm{kg})$ of cows calved during period $\mathrm{P}_{1}(220.13 \pm 12.79)$ was significantly higher than those in $\mathrm{P}_{2}(138.25 \pm 12.69)$ and $\mathrm{P}_{3}$ $(137.00 \pm 17.27)$ which were significantly different from each other. The results revealed that the monthly milk yield of seventh month linearly decreased in cows calved during succeeding periods over preceding i.e. $\mathrm{P}_{1}$ to $\mathrm{P}_{3}$ in Phule Triveni cows.

The variation due to season of calving in monthly milk yield of seventh month was significant $(\mathrm{P}<0.01)$ in Phule Triveni cows. This result was in accordance with Kale et al., (2001a) in Triple cross bred. However contradictory results were obtained by Deokar et al., (2017) in HF $\times$ Girhalfbreds, Kamble (2014) in Phule Triveni cows, Pandey et al., (2018) and Raja (2019) in Sahiwal cattle.

In Phule Triveni cows, the highest MMY7 (kg) was observed in cows calved during winter $(191.70 \pm 13.85 \mathrm{~kg})$ followed by rainy $(170.84 \pm 14.61 \mathrm{~kg})$ and lowest in summer $(132 . \pm 14.45 \mathrm{~kg})$.In Phule Triveni cows in the 
present study no specific trend of season of calving was noticed for MMY7.

The difference due to order of lactation monthly milk yield of seventh month was non-significant in Phule Triveni cows. In Phule Triveni, the highest MMY7 (kg) was observed during $\mathrm{L}_{3}(179.05 \pm 17.43)$ followed by, $\mathrm{L}_{4}(172.31 \pm 19.76), \mathrm{L}_{2}(164.53 \pm 16.01)$, $\mathrm{L}_{5}(160.02 \pm 22.81)$ and lowest in $\mathrm{L}_{1}(149.72 \pm$ 15.62)lactation. In Phule Triveni cows in the present study no specific trend was noticed for MMY7 in various lactations.

\section{Eighth monthly milk yield}

The overall least squares mean of monthly milk yield of eighth month in Phule Triveni cows was $168.05 \pm 7.49 \mathrm{~kg}$.

The influence of period of calving on monthly milk yield of eighth month was significant $(\mathrm{P}<0.01)$ in Phule Triveni cows. Similar results were reported in $\mathrm{HF} \times$ Girhalfbreds (Deokaret al., 2017), Phule Triveni cows (Kamble 2014), Kale et al., (2001a) in Triple cross bred. In Phule Triveni cows, monthly milk yield of eighth month $(\mathrm{kg})$ of cows calved during period $\mathrm{P}_{1}(215.19 \pm 11.14)$ was significantly higher than those in $\mathrm{P}_{3}(147.67 \pm$ 12.29) and $P_{2}(141.28 \pm 11.59)$ which were at par to each other. The MMY8 $(\mathrm{kg})$ among total cows calved during period $\mathrm{P}_{2}$ and $\mathrm{P}_{3}$ were at par with each other. The results revealed that the monthly milk yield of eighth month there was no specific trend observed in Phule Triveni cows.

The variation due to season of calving in monthly milk yield of eighth was nonsignificant in Phule Triveni cows. This result was in accordance with Deokar et al., (2017) in HF X Girhalfbreds, Kamble (2014) in Phule Triveni cows, Pandey et al., (2018) and Raja (2019) in Sahiwal cattle. However contradictory results were obtained by Kale $e t$ al., (2001a) in Triple cross bred. In Phule Triveni, the highest MMY8 (kg) was observed in cows calved during season winter $(184.49 \pm 12.15)$ than rainy season $(172.28 \pm 13.04)$ and lower in summer season of calving (147.37 \pm 12.29$)$.

The difference due to order of lactation in monthly milk yield of eighth month $(\mathrm{kg})$ was non-significant in Phule Triveni. Contradictory results were obtained by Kale et al., (2001a) in Triple cross bred. In Phule Triveni cows, the highest MMY8 (kg) was observed in cows calved during $\mathrm{L}_{3}$ (193.97 \pm 15.33$)$ followed by $\mathrm{L}_{2}(170.50 \pm$ 14.40), $\quad \mathrm{L}_{5} \quad(166.81 \pm 19.86), \mathrm{L}_{4} \quad(158.58 \pm$ 18.03) and lowest in $\mathrm{L}_{1}(150.38 \pm 13.61)$ lactation. In Phule Triveni cows in the present study no specific trend was noticed for MMY8 in various lactations.

\section{Nineth monthly milk yield}

The overall least square mean of monthly milk yield of ninth month in Phule Triveni cows was $162.12 \pm 8.14 \mathrm{~kg}$. The influence of period of calving on monthly milk yield of ninth month $(\mathrm{kg})$ was significant $(\mathrm{P}<0.05)$ in Phule Triveni cows. Similar results were reported by Kale et al., (2001a) in Triple cross bred. In Phule Triveni cows, monthly milk yield of ninth month $(\mathrm{kg})$ of cows calved during period $\mathrm{P}_{1}(188.27 \pm 10.60)$ was significantly higher than those in $\mathrm{P}_{3}(156.33 \pm 16.47)$ and $\mathrm{P}_{2} \quad(141.76 \pm 12.68)$ which were significantly different from each other. The differences obtained among the cows calved during period $\mathrm{P}_{1}$ and $\mathrm{P}_{3}, \mathrm{P}_{3}$ and $\mathrm{P}_{2}$ were at par to each other. The results revealed that the monthly milk yield of ninth month there was no specific trend of period of calving noticed in Phule Triveni cows.

The variation due to season of calving in monthly milk yield of ninth month was significant $(\mathrm{P}<0.05)$ in Phule Triveni cows. In 
Phule Triveni, the highest MMY9 (kg) was observed in cows calved during season rainy $(189.86 \pm 13.59 \mathrm{~kg})$ followed by winter $(155.03 \pm 11.70 \mathrm{~kg})$ and lowest in summer $(141.47 \pm 13.94 \mathrm{~kg})$. The differences obtained among the cows calved during season $S_{1}$ and $S_{2}$ and $S_{2}$ and $S_{3}$ were at par to each other.

The difference due to order of lactation in total milk yield $(\mathrm{kg})$ was non-significant in Phule Triveni. In Phule Triveni cows, the highest MMY9 $(\mathrm{kg})$ was observed in cows calved during $\mathrm{L}_{3}(180.03 \pm 15.48)$ followed by $\mathrm{L}_{2}$ (164.04 \pm 14.35$), \mathrm{L}_{4}(158.78 \pm 19.86), \mathrm{L}_{5}$ (155.36 \pm 21.93$)$ and lowest in $\mathrm{L}_{1}(152.40 \pm$ 13.39) lactations.

\section{Tenth monthly milk yield}

The overall least square mean of monthly milk yield ofttenth month in Phule Triveni cows was $146.12 \pm 7.95 \mathrm{~kg}$.

The influence of period of calving on monthly milk yield of tenth month was significant $(\mathrm{P}<0.01)$ in Phule Triveni cows. Similar results were reported by Kale et al.(2001a) in Triple cross bred $(185.15 \pm 4.97)$. In Phule Triveni, monthly milk yield of tenth month $(\mathrm{kg})$ was highest in cows calved during period $\mathrm{P}_{1}(179.71 \pm 10.90)$ followed by $\mathrm{P}_{3}(139.65 \pm$ 15.17) and lowest in $P_{2}(118.99 \pm 12.49)$. The differences obtained among the cows calved during period $\mathrm{P}_{1}$ and $\mathrm{P}_{3}$ and between $\mathrm{P}_{3}$ and $\mathrm{P}_{2}$ were at par to each other. The results revealed that the monthly milk yield of tenth month had not specific trend in various period of calving.

The variation due to season of calving in monthly milk yield of tenth month was nonsignificant in Phule Triveni cows. This result was in accordance with Deokar et al., (2017) in HF $\times$ Girhalfbreds, Kamble (2014) in Phule Triveni cows, Pandey et al., (2018) and Raja (2019) in Sahiwal cattle, Kale et al., (2001a) in Triple cross bred. In Phule Triveni, the highest MMY10 was observed in cows calved during rainy $(153.70 \pm 12.91 \mathrm{~kg})$ followed by summer $(152.29 \pm 14.15 \mathrm{~kg})$ and lowest in winter $(132.35 \pm 11.36 \mathrm{~kg})$.

The difference due to order of lactation in monthly milk yield of tenth month $(\mathrm{kg})$ was non-significant in Phule Triveni cows. Similar results were obtained by Kale et al.(2001a) in Triple cross bred. In Phule Triveni cows, the MMY10 (kg) was observed in cows calved during $\mathrm{L}_{5}(169.96 \pm 22.81)$ followed by $\mathrm{L}_{2}$

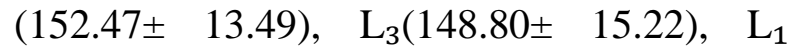
(135.45 \pm 12.99$)$ and lowest in $\mathrm{L}_{4}(123.90 \pm$ 19.38) lactation. In Phule Triveni cows, in the present study no specific trend was noticed for MMY10 in various lactations.

\section{References}

Behera R., Mandal A. ,Rai S., Karunakaran M. and Mondal M. (2020). Temperature Humidity Index and its relationship with production traits of dairy cattle and buffaloes - Review. International Journal of Livestock Research 10(3):3848.

Deokar, D. K., Raut D. R., Bhoite U. Y., Gaikwad U. S. and Mandakmale S. D. (2017). Prediction of 305 days milk yield from part lactation records in $\mathrm{Hf} \mathrm{x}$ Girhalfbred cows. Contemporary Research in India 7(2):193-196.

Harvey W.R. (1990).Least-squares analysis of data with unequal subclass numbers. ARS H-4, U.S.D.A, Washington.

Jadhav, P.N. (1993). Studies on peak yield, total milk yield and their correlation in FJG and their inbreds. M.Sc. (Agri.) Thesis, submitted to MPKV, Rahuri (India).

Jebale, K.P. (1994). Studies on peak yield, total milk yield and their correlation in BFG and their interbreeds. M.Sc. (Agri.) Thesis submitted to M.P.K.V., 
Rahuri.

Kale, D.D., Ulmel B.R., Deokar, D.K. and Pachpute, S.T. (2001). Genetic studies on lactation milk yield in Triple crossbred cows. J. Maharashtra Agric. Univ. 26(3): 316-319.

Kamble S.M. (2014). Prediction of 305 days milk yield from part lactation records in Phule Triveni cows. M.sc.(agri.) thesis submitted to M.P.K.V. rahuri.

Kramer, C.V. (1957). Extension of multiple range test to group correlated adjusted mean. Biometrics, 13: 13-20.

Naikare, B.D. (1993). Studies on part lactation and lifetime milk production in two and three breed Gir crosses. Ph.D. Thesis submitted to M.P.K.V., Rahuri.

Pandey M. and Raja K.N. (2019). Analysis of non-genetic factors influencing monthly test day milk yield records in Sahiwal cattle. Bulletin of Environment, Pharmacology and Life Sciences Bull. Env. Pharmacol. Life Sci., 8(9):98-101.

Pandey M. and Raja K.N., Saleem Yousuf and Gupta A.K. (2018). Effect of nongenetic factors on first lactation 305 days and lifetime milk yield in Sahiwal cattle. Indian J Dairy Sci 72(1): 89-92.

Patil, V.S. (1989). Studies on effect of peak yield on total milk yield in Friesian $\mathrm{x}$ Gir. M.Sc. (Agri.) Thesis, submitted to MPKV, Rahuri (India).

Raut, D.R., Deokar, D.K., Bhoite, U.Y., Gaikwad, U.S., andMandakmale, S.D., (2017). Prediction of 305 days milk yield from part lactation record in $\mathrm{HF}$ Girhalf bred cows. Contemporary Research in India. 7(2):193-196.

\section{How to cite this article:}

Swapnali Uttamrao Rokade, Dilip Kundalik Deokar, Ghoshita Suryakant Hingonekar and Harshavardhan Shahaji Sonawane. 2021. Effect of Non-genetic Factors on Monthly Milk Yield for Phule Triveni Cattle. Int.J.Curr.Microbiol.App.Sci. 10(01): 124-133.

doi: https://doi.org/10.20546/ijcmas.2021.1001.014 